\title{
A very rare discomycete, Octospora maireana, found in Finland
}

\author{
BELLIS KULLMAN
}

\begin{abstract}
KULLMAN, B. 1997: A very rare discomycete, Octospora maireana, found in Finland. - Karstenia 37:27-31. Helsinki. ISSN 0453-3402

The first record of Octospora maireana (Seaver) Yei-Zeng Wang (Pezizales) from Europe outside the Mediterranean area is described and illustrated with drawings and with micrographs obtained by optical and scanning electron microscopy. The worldwide occurrence of this species is characterized. The morphological features of the spores and the fruitbody of $O$. maireana from Finland do not differ from those of the previously known five specimens found in North Africa, North America, Australia and South Europe.
\end{abstract}

Key words: Ascomycetes, Finland, Pezizales, Octospora maireana, taxonomy, morphology, scanning electron microscopy

Bellis Kullman, Institute of Zoology and Botany of the Estonian Academy of Sciences, 181, Riia St., EE 2400 Tartu, Estonia

\section{Introduction}

Octospora maireana (Seaver) Yei-Zeng Wang (Pezizales, Pyronemataceae) has been found on five occasions: in North Africa (Seaver 1912, 1914, 1928, 1961), North America (Seaver 1914, 1928, 1961), Australia (Rifai 1968) and southern Europe (Ortega \& Buendia 1987) and now Finland.

The specimen from Finland was found during a mycological excursion to the Åland (Ahvenanmaa) Islands on Sept. 9-13, 1991. This was the second similar undertaking within the framework of a scientific collaboration between Estonian and Finnish mycologists (Institute of Zoology and Botany and the University of Turku, respectively).

\section{Materials and methods}

In the course of this study I studied specimens of Octospora from TAA and NY.
A fresh specimen from Finland was fixed in $4 \%$ glutaraldehyde in phosphate buffer ( $\mathrm{Ph} 7)$. The specimen was placed through a gradual ethanol series, into $100 \%$ ethanol, after which it was critical-point dried, coated with a $20-\mathrm{nm}$ layer of gold, and examined and photographed under a Tesla BS 301 scanning electron microscope.

The fungal fruitbodies were measured with the microscope "Amplival" and drawn by means of the drawing apparatus PA-6, using the objective 40 and the immersion objective HI 100. A solution of cotton blue in lactophenol was used as research medium.

The length (l) and width (w) of the spores are presented in the following form: (lmin)-lmean(lmax) x (wmin)-wmean-(wmax) $\mu \mathrm{m}$, where lmean and wmean denote the mean values of 20 spore lengths and widths within a specimen, and lmin, wmin and lmax, wmax the minimum and maximum absolute values of length and width, respectively. 


\section{Description}

Octospora maireana (Seaver) Yei-Zeng Wang, Spec. Publ. Natl. Mus. Nat. Sci. Taiwan 4:41. 1992. - Lamprospora maireana Seaver, Mycologia 6:14. 1914.

Type: Algeria, Algiers, on moist ground among mosses, 1.2.1912, Maire (NY, holotype, as Lamprospora tuberculata).

Apothecia gregarious, at first globose, expanding to cup-shaped 1-2 $\mu \mathrm{m}$ in diam, yellowish-orange, hymenium slightly concave, sheathed with thin film when young. Receptacle darker than hymenium, with a broad margin. Excipulum indistinctly two-layered with a narrow ectal excipulum $30-40 \mu \mathrm{m}$ thick, consisting of small thin-walled interwoven hyphae (textura intricata), 6-10 $\mu \mathrm{m}$ in diam, and an ental layer (medulla), 90-100 $\mu \mathrm{m}$ thick, of coarser interwoven hyphae, $8-15 \mu \mathrm{m}$ in diam (textura intricata). The hyphae reorientate towards the margin of the receptacle, their cells becoming longer and more regularly arranged, running parallel with the surface of the receptacle (textura porrecta), and up to $10 \mu \mathrm{m}$ in diam by the obtuse $20-50 \mu \mathrm{m}$ long endcells of cylindrical, slightly clavate hair-like hyphae which form the subhyaline or yellowish dentate-fimbriate margin. Subhymenium of interwoven hyphae, 30-40 $\mu \mathrm{m}$ thick (textura intricata), 4-6 $\mu \mathrm{m}$ in diam. Hymenium 300-310 $\mu \mathrm{m}$

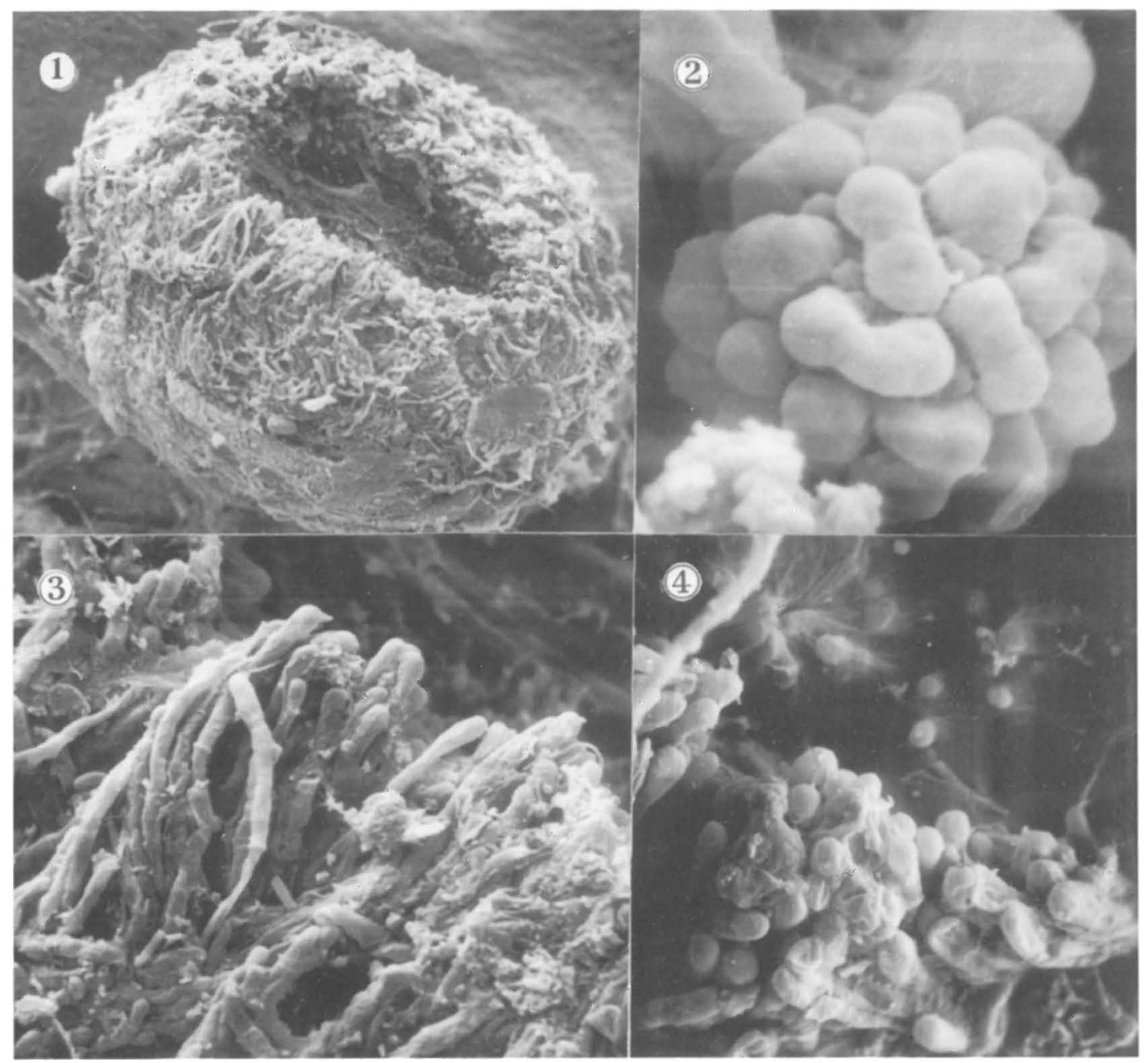

Figs. 1-4: Octospora maireana (Kullman \& Höijer, TAA 117649). -1: Young apothecium. — 2: Ascospore. — 3-4: Margin of apothecium. 
thick. Asci 8-spored, clavate cylindrical, narrower towards the base, $280-340 \times 23-30 \mu \mathrm{m}$. Ascospores globose, uniseriate, hyaline (18.9)20.4-(21.4) $\mu \mathrm{m}$ excluding ornaments; tubercles rounded or somewhat flattened, 4.5-5.5 x 1.8-3 $\mu \mathrm{m}$ with many small guttules inside. Paraphyses straight, 4-6 $\mu \mathrm{m}$ in diam below, increasing at the apex up to $8 \mu \mathrm{m}$.

\section{Specimen examined}

Finland, Ahvenanmaa (A), Sandösund, grid $27^{\circ} \mathrm{E}$ 670:13, at the seaside, on very moist sand among mosses of the genus Bryum, 12.9.1991, Kullman \& Höijer (TAA 117649).

Known distribution of $O$. maireana (Fig. 6): United States: New York (Seaver 1928), Virginia (Wang \& Kimbrough 1992); Australia (Rifai 1968); Portugal (Ortega \& Buendia 1987); Algeria (Seaver 1924); Finland.

The species has not yet been found in Europe in the temperate zone but has been reported from the meridional (Algeria), submeridional (United States, Portugal) and tropical/austrosubtropical (Australia) zones. (Terms of floristic regions and zones follow Meusel et al. 1965, Sedlag \& Weinert 1987.) It is a subtropical-warm temperate (term introduced by Schumacher 1990) transcontinental species, evidently preferring moist climate.
Illustrations: Seaver 1912: pl. 114, f. 13; Rifai 1968: f. 197-200; Benkert 1987: Abb. 9, f. 5-7, Abb. 18, f. 5; Ortega \& Buendia 1987: f. 10; Wang \& Kimbrough 1992: f. 13, 19, 39, 55, 56.

\section{Discussion}

The spore ornamentation of Octospora mairea$n a$ is unique in the genus (Fig. 2). There are many interior guttules inside tubercles, which are visible under the optical microscope (Fig. 5, 8). The interior guttules dissolve rapidly in $2 \%$ $\mathrm{KOH}$ (Wang \& Kimbrough 1992). In SEM the

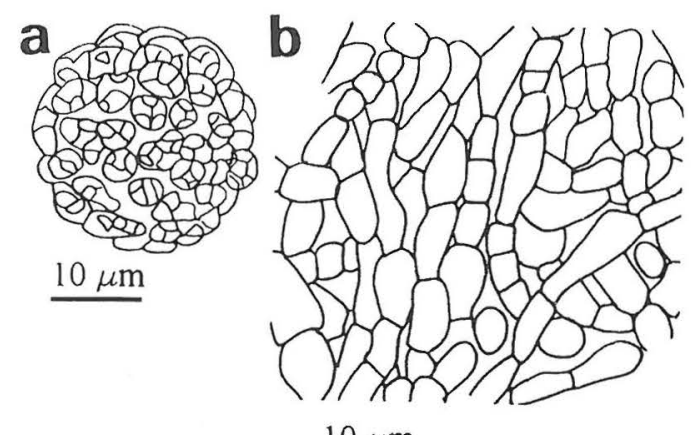

Fig. 5a-b. Octospora maireana (Kullman \& Höijer, TAA 117649). - a) ascospore, b) section of medulla.

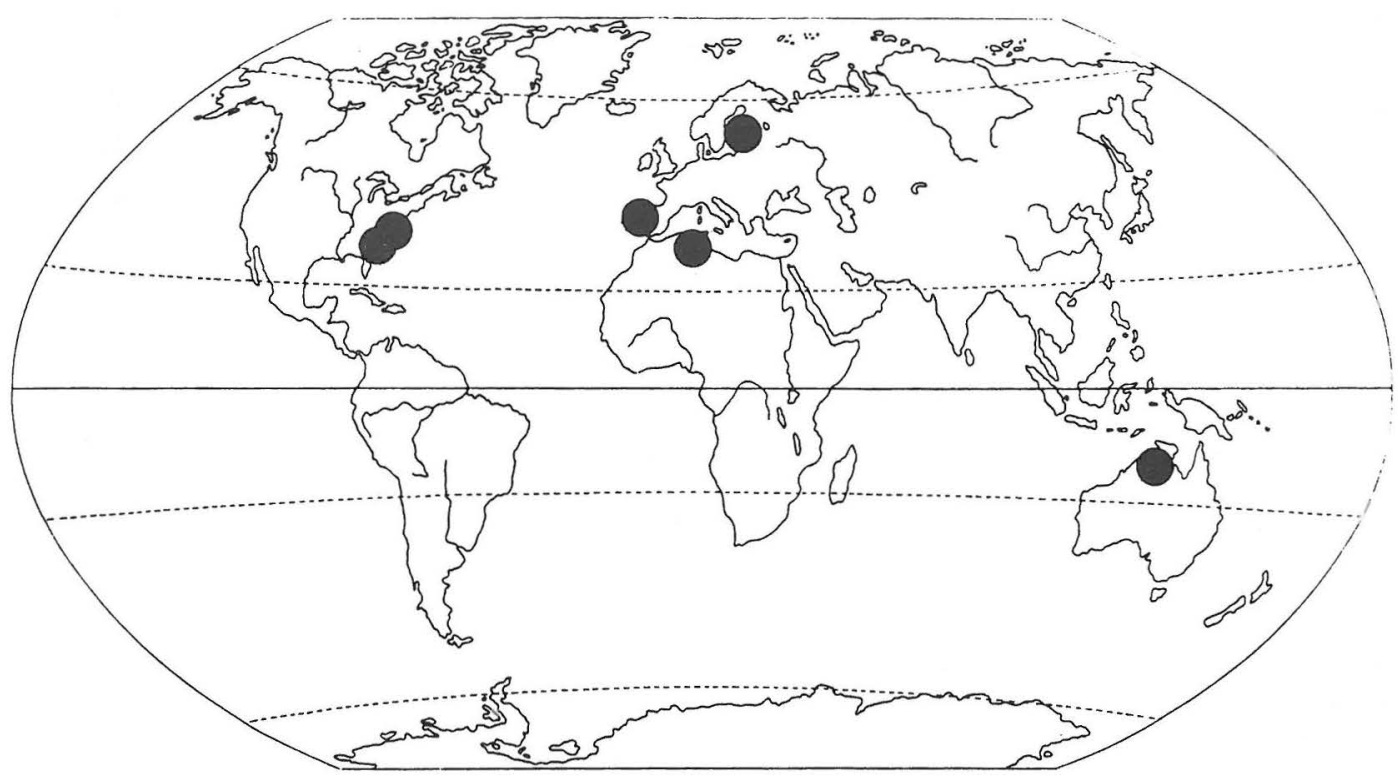

Fig. 6. Known distribution of Octospora maireana. 
ornamentation of the ascospores of $O$. maireana, Lamprospora tuberculata Seaver and L. rehmii Benkert (Benkert 1993) (the two last species most likely belonging to Octospora) is very similar, but the two last have tubercles without guttules.

The type specimen $O$. maireana and the specimen from North America (New York, New York City, 29.10.1913, Seaver, NY) studied by the author are very similar in spore ornamentation to the present specimen.

The spore measurements of the type are (17.6)-19.2-(20.2) $\mu \mathrm{m}$ in diameter. The spores of TAA 117649 are somewhat larger than these,
(18.9)-20.4-(21.4) $\mu \mathrm{m}$, but somewhat smaller than those reported in the literature: $23 \mu \mathrm{m}$ (Seaver 1961); 20-23 $\mu \mathrm{m}$ (Rifai 1968); 18-22(24) $\mu \mathrm{m}$ and (20)-22-26 $\mu \mathrm{m}$, the last measurements including ornaments (Wang \& Kimbrough 1992). The type specimen has paraphyse apices 6.3-8.2 $\mu \mathrm{m}$ in diam. The medulla, 290-320 $\mu \mathrm{m}$ thick, consists of coarse interwoven hyphae, 8$12.8 \mu \mathrm{m}$ in diam, with textura intricata (Fig. 9), not textura angularis as described by Wang \& Kimbrough (1992). The margin is composed of long clavate hair-like hyphae (textura porrecta), apex diameter is $6.3-16 \mu \mathrm{m}$. The margin is 130 $\mu \mathrm{m}$ thick.

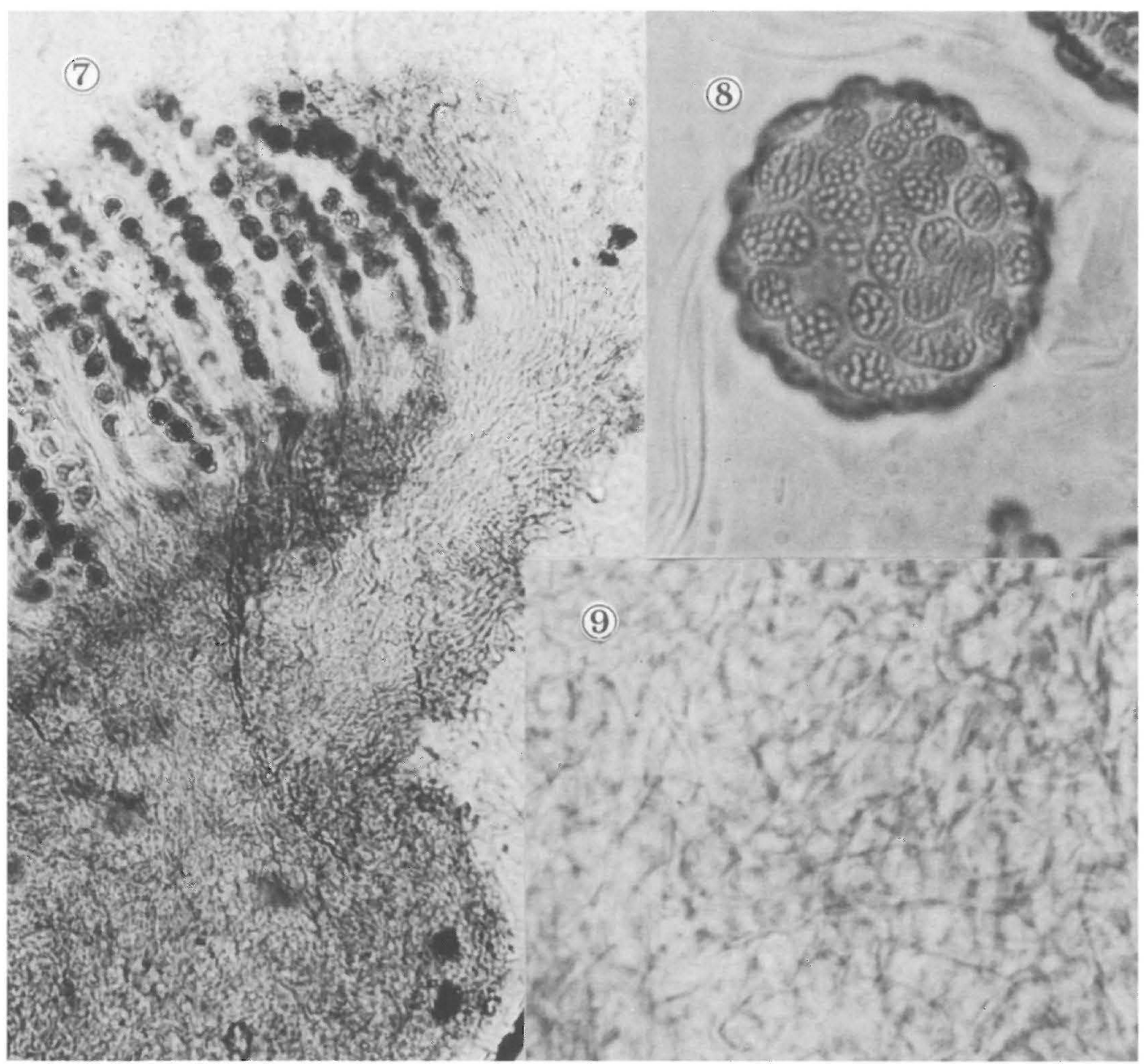

Figs. 7-9. Type specimen of Octospora maireana. - 7: Apothecium. 8: Ascospore - 9: Medulla. 
O. maireana has been described as a bryoparasite growing on the ground among mosses and algae (Seaver 1928); on the moss species of liverwort (Metzgeriales), Pottiaceae and Bryum sp. (Benkert 1987); and associated with liverwort, Fossombronia sp. and moss species of Pottiaceae (Wang \& Kimbrough 1992). So far it is not quite clear which moss acts as host. Our specimen is associated with young Bryum sp.

Acknowledgements. My sincere thanks are due to the Herbarium of the New York Botanical Garden for lending herbarium material. I thank Mr. Paavo Höijer (Porvoo, Finland) for help in field work, Dr. Mart Rahi (Institute of Zoology and Botany of the Estonian Academy of Sciences) for assistance in work with SEM, Mr. Aivo Jakobson (University of Tartu) for the preparation of the holotype specimen of $O$. maireana and for taking the photos and drawing the holotype (Figs. 5, 7-9), Ms. Nele Ingerpuu (Institute of Zoology and Botany) for the identification of the moss Bryum sp., and Ms. Ester Jaigma for revising the English text of the manuscript.

\section{References}

Benkert, D. 1987: Beiträge zur Taxonomie der Gattung Lamprospora (Pezizales). — Z. Mykol. 53:195272.

Benkert, D. 1993: Beiträge zur Kenntnis bryophiler Pezizales-Arten. 3. Lamprospora rehmii. - Beiträge zur Kenntnis der Pilze Mitteleuropas 9:139-142.
Meusel, H., Jäger, E. \& Weinert, E. 1965: Vergleichende Chorologie der zentraleuropäischen Flora I. $-582+258$ pp. Fischer, Jena.

Ortega, A. \& Buendia, A. G. 1987: Contribucion al estudio de la tribu Aleurieae Seaver emend. Korf en la Peninsula Iberica. - Cryptogamie, Mycol. 8:125-140.

Rifai, M. A. 1968: The Australasian Pezizales in the Herbarium of the Royal Botanical Gardens Kew. - Verh. Koninkl. Nederl. Akad. Wet. II, 57:1295.

Schumacher, T. 1990: The genus Scutellinia (Pyronemataceae). - Opera Bot. 101:1-107.

Seaver, F. J. 1912: The genus Lamprospora with description of two new species. - Mycologia 4:43-48.

Seaver, F. J. 1914: A preliminary study of the genus Lamprospora. - Mycologia 6:5-24.

Seaver, F. J. 1928: The North American Cup-fungi (Operculates). - 284 pp. New York.

Seaver, F. J. 1961: The North American Cup-fungi (Operculates). - 428 pp. New York.

Sedlag, U. \& Weinert, E. 1987: Biogeographie, Artbildung, Evolution. - 333 pp. Fischer, Jena.

Wang, Y. Z. \& Kimbrough, J. W. 1992: Monographic studies of North American species of Octospora previously ascribed to Lamprospora (Pezizales, Ascomycetes). - Spec. Publ. Natl. Mus. Nat. Sci. Taiwan 4:1-68.

Received on 10 November 1995 